\title{
An evaluation of the limitations of the corporate governance codes in preventing corporate collapses in Nigeria.
}

\author{
Adenike Adewale
}

\begin{abstract}
The drive for monetary success has the tendency for corporate executives to exploit and/or disregard regulatory controls for the sake of financial gain. This research evaluates the limitations of the corporate governance codes in Nigeria in preventing collapses. A background into the development of corporate governance in Nigeria is evaluated. Furthermore, the Nigerian corporate governance frameworks, its implementation, challenges and effectiveness would be assessed. The qualitative research method was employed to collect information. Descriptive data and critical analyses methods are used to compare the corporate governance codes.
\end{abstract}

Keywords: Collapses, Corporate governance codes, Limitations

\section{Introduction}

Corporate collapses all over the world may have occurred due to specific circumstances attached to each country's government and regulatory policies, goals and financial capabilities; there seems to be one common reason: failure to adopt effective governance that has resulted in inefficient business decisions (Kariyawasam (2011)). A survey by the World Bank of sixty (60) developing nations identified lack of transparency and disclosure and corruption among firms in developing countries as the single greatest impediment to economic development in developing countries such as Nigeria.

Corporate governance provides the structure through which the corporation's objectives are set and attained and provides a means of monitoring problems. The corporate governance of corporations specifies the distribution of rights and responsibilities among the different participants, spelling out the rules and procedures for decision making. It is a means of promoting corporate fairness, transparency and accountability. Corporate governance is responsible for the structures and systems of control by which managers are held accountable to those who have a legitimate stake in an organisation. Adekoya (2011) suggests that without good corporate governance, corporate performance cannot be measured, corporate governance aims at promoting corporate transparency and accountability. Mellahi (2005) further argues that the failure of organisations is caused by the negligence of the top management in providing good governance.

This research evaluates the problems of corporate governance in Nigeria. It further evaluates limitations of the corporate governance codes in Nigeria preventing corporate collapses in an economy like Nigeria. It emphasises the importance of effective corporate governance codes and proper implementation in preventing corporate collapses.

\section{Literature Review}

\subsection{Corporate Governance frameworks in Nigeria}

According to Okpara (2011) corporate accountability gained importance in the post structural adjustment program (SAP) era in Nigeria. This era noted the growth of privately owned corporations and financial institutions. In Nigeria, the informal nature of most business and the high level of government ownership enterprises pose challenges to the practice of corporate governance.

A survey of enterprises in six randomly selected states in Nigeria conducted by the Development Policy Centre in 1999 found that only $13.3 \%$ of Nigerian companies were listed on the stock Exchange. The results showed that close to $38 \%$ of businesses may be operating outside the purview of the company law provisions (operating as partnerships or sole proprietorships) while close to $87 \%$ of businesses operated outside the scope of stock exchange regulations (Oyejide and Soyebo 2001).

As a result of this weak corporate culture in these institutions, Nigeria witnessed a very high incidence of corporate failures. The need to develop and promote good corporate governance in Nigeria led to the Securities and Exchange Commission setting up a committee in 2003 whose report yielded the first comprehensive code of best practices for public companies in Nigeria. This was an attempt to regain the confidence of the public. The 2003 Code of Best Practices on Corporate Governance in Nigeria issued by the Securities Exchange Commission was developed based on the UK combined Code and the Sarbanes Oxley in the United States. It emphasises the role of the board of Directors and management, shareholder rights and privileges and the audit committee. In 2006, the Central Bank of Nigeria issued the Code of Corporate Governance for Banks in Nigeria Post Consolidation. 
This code was introduced to ensure the accountability of bank CEOs. It describes board composition and the qualifications of non-executive directors. It specifies the accountability structure within the organisation. It specifies fines and penalties including jail term for erring CEOs. It also specifies risk management measures within the organisation emphasising on the roles and qualifications of corporations' internal auditor. Challenges to Corporate Governance in Nigeria

\subsection{Banking Industry}

According to Adegbite (2010) poor corporate governance was one of the major factors in virtually all known cases of distresses experienced by financial institutions in Nigeria. In the wake of the consolidation which took place in 2005, Nigerian banks experienced an explosive balance sheet growth and they went on massive capital-raising sprees. This increased their lending capacity to companies and private persons. However, risk-management, did not keep pace.

The issues in the Nigerian banking sector, such as unethical and potentially fraudulent business practices, to weaknesses in the corporate governance of the banks was attributed to the failure of banks. The consolidation created bigger banks but failed to overcome the fundamental weaknesses in corporate governance in many of these banks. Corruption in the Nigerian banking sector is argued as been responsible for the collapse of many banks in the 1990s and losses to many depositors and stakeholders.

However, Emmanuel (2011) argues that the failure of some Nigerian banks was due to the fraudulent practices committed by bank owners and managers who had granted unsecured loans to their friends and themselves. This resulted in high levels of bad debts and a loss of liquidity. He also identified the failure to maintain a strong capital base and the unconcealed embezzlement of funds in some cases. In relation to the failures in the Nigerian banking system, the CBN confirmed that the management of the failed banks acted conducted their affairs in ways detrimental to the interests of their depositors and creditors.

According to Otusanya (2010) the CBN Governor identified the following inter-dependent factors as responsible for the failures in corporate governance in the banks; lack of investor and consumer sophistication, inadequate disclosure and transparency as to the financial position of the banks, critical gaps in the regulatory framework and regulations, uneven supervision and enforcement, unstructured governance and management processes at the $\mathrm{CBN}$ and weaknesses within the business environment.

\subsection{Manufacturing industry}

According to Amaeshi (2006) the Nigerian legal enforcement and regulatory framework are weakened and made inefficient by institutionalised corruption which has been widely accepted as the cause of poor corporate governance. A culture of political patronage was fostered on the country by the ruling class of politicians who often appoint their cronies as board members of government agencies and use them to award bogus or inflated contracts to private corporations in which they have controlling interest.

The effectiveness of the agencies set in fighting corruption is influenced by these politicians. Political influences prevent the law enforcement agencies from investigating their financial crimes. Corrupt practices of the political elite affects law enforcement agencies put in place to support effective governance. These corrupt practices and abuse of official privileges have made Transparency International to consistently list Nigeria as one of the most corrupt countries in the world.

However, corruption alone cannot be blamed for the persistent corporate governance failures in Nigeria. These include socio-political, economic and cultural factors which create the dismal corporate governance environment. Major scandals such as that of Cadbury Nigeria have brought corporate governance discussions to a high point in academic, practice and policy debates.

Okpara (2011) identified constraints that hinder the implementation and promotion of corporate governance in Nigeria. These include weak or non-existent law enforcement mechanisms, abuse of shareholders' rights, lack of commitment on the part of boards of directors to their responsibilities, lack of adherence to the regulatory framework, weak enforcement and monitoring systems, and lack of transparency and disclosure. According to the CBN (2006), many board members lack the requisite skills and competencies to effectively contribute to the leadership of modern corporations. Wide spread poverty caused by high unemployment and failing standard of education also affect effective corporate governance in Nigeria. These often lead to ignorance of perceived crimes even when identified, whistle-blowing on unethical corporate practices or professional misconduct is also not encouraged. According to Adeyemi (2011) whistle-blowers often become the victims of oppression instead of being protected and rewarded for their acts.

Nigeria has laws designed to protect shareholders' rights and ensure good corporate governance, but effective enforcement of existing laws and regulations constitutes a major challenge for the development and implementation of corporate governance. Furthermore, the strict rights and entitlements that come with the ownership of shares in listed companies are not fully exploited by shareholders largely because they are unaware of these rights and this fact is abused by top management and boards of directors. 


\subsection{Effectiveness of corporate governance agencies}

There are standards and laws put in place and penalties for violations. However, supervision of corporations and the enforcement of these laws prove to be problematic. According to Ugoji and Isele (2009) the key avenue prescribed by the CAMA for enforcing the shareholders rights is the courts. However, Nigerian courts remain slow, expensive and ineffective in resolving commercial disputes. The judicial system has been ineffective in enforcing these laws.

As a result of these, shareholders are hesitant to use the courts allowing the directors to continue to rule with impunity. The extra-judicial systems expected to bring pressure on the board of directors have also failed. These extra-judicial systems include shareholders' associations and the registrar of companies. This faulty judicial system can also be linked to the political and institutionalised corruption already discussed.

According to Adegbite (2012) the Company and Allied Matters Act (CAMA) 1992 enacted to regulate and balance the relationship among the board of directors, shareholders and other stakeholders failed due to inadequate enforcement. The regulatory bodies in Nigeria such as the CBN, the Security and Exchange Commission (SEC) and the Corporate Affairs Commission (CAC) entrusted with the monitoring of corporations and the enforcement of the corporate governance codes are staffed with self-interested executives who easily and readily collaborate with company's senior executives to compromise shareholder interests. These board members are usually picked from the pool of high profile retired senior military officers and civil servants without expertise in basic finance and business operations (Okpara 2011).

\section{Methodology}

According to Saunders (2009) Research methodology explains research methods used, objectives of the research, sources of data collection and research limitations faced by the researcher. It provides access to information, time, money, location and ethical concerns faced by the researcher.

\subsection{Scope of study}

This study would make use of three (3) case studies. The use of case studies was chosen because of the qualitative nature of analysis. Qualitative nature shows the relationship between the processes. This makes the use of case studies suitable in depicting the challenges to corporate governance. Case studies would exemplify the relationship between the corporate failures, scandals and lapses in effective corporate governance. Three corporations, Cadbury Nigeria, Intercontinental Bank Plc and Oceanic Bank Plc would be used in the analysing corporate governance failures in Nigeria.

\subsection{Data Analysis Technique}

According to Bryman and Bell (2007) the nature of investigation to be carried out and the availability of resources determine the choice of research technique and data collection measures to be used. The primary objective of the study is to examine the effectiveness of corporate accountability within Nigerian corporations by evaluating the measures put in place and the challenges faced in enforcing them. In using the qualitative analysis methods words would be used in analysing the data available. The specific objectives of this dissertation are as follows;

Objective 1- to assess the challenges to corporate accountability in Nigeria

The case studies chosen for this research show the challenges faced by corporations in Nigeria. Some of these challenges are industry based while some cut across all industries. This research uses case studies from two industries (manufacturing and banking). It identifies the causes of their failures and the scandals that ensued afterwards. These causes identified from the studies are evaluated using the corporate governance codes in Nigeria and the Company and allied matters act which are the regulatory laws guiding corporations. In evaluating the collapse of these case studies, challenges to corporate accountability would be ascertained.

Objective 2- to examine the causes of these challenges

The causes of the challenges will be evaluated using the case studies listed above. The underlying factor of the challenges discovered from the case studies will be evaluated. The corporate governance practices in the failed institutions are compared to that of another corporation within the same industry in trying to identifying some of the causes of the challenges identified from the case studies above.

Objective 3 - to assess the enforcement of the measures that has been put in place

There are different regulatory bodies in Nigeria. This bodies either failed to identify the corporate governance problems in organisations in Nigeria or failed prevent them in causing collapses. The ability of these regulatory bodies in identifying malfeasance would be evaluated. The efficiency of the Nigerian regulatory bodies in enforcing current rules would be further evaluated. 


\subsection{Overview}

\section{Analysis}

In October 2008, the CBN discovered that some of the banks in the country were showing liquidity strain due to extensive use of its 'expanded discount window' (EDW) which extended credit facilities to banks on the basis of collateral in the form of commercial paper and bankers' acceptance. In 2009, joint inspectors from the CBN and the Nigerian Deposit Insurance Corporation (NDIC) were given the task of examining the books of banks. Most of these banks were found to be experiencing liquidity problems and were directed to obtain an injection of capital as long-term loans and liquidity support. This discovery by the inspectors resulted in the chief executive directors and a number of executive directors of wanting banks being replaced with new ones appointed by the CBN (Saturday Tribune, 3 October 2009). The dismissed bank executives were accused of violating financial regulations governing banks. Loans had been granted without adequate collateral. These loans remained un-serviced and included loans to these executives and their friends.

\subsection{Case Studies}

\section{Case 1 - Intercontinental Bank}

Intercontinental Bank Plc was a leading commercial bank in Nigeria. For almost two decades, Intercontinental bank was listed as one of Nigeria's five leading banks. Its former bank Chief Executive, Erastus Akingbola was always respected in the news on how far he had taken the bank in terms of its balance sheet earnings, international recognition, awards and ratings. The bank's auditors continually confirmed the financial institution as a going concern and its books, shareholders were led to believe as true and fair. Contrarily, Intercontinental Bank was seriously ailing.

In 2009, after examining the bank's records, the CBN Governor discovered that Intercontinental Bank Plc was troubled. It was unable to meet its maturing obligations without persistent recourse to the EDW of the CBN and was in dire need of capital. The bank showed excessive liquidity stress with its persistent use of the EDW. The Akingbola led management had accumulated up to N210.9 billion non-performing loans (The News, 14 September 2009). The EFCC alleged that Akingbola had engaged in serious economic and financial (EFCC News, 25 August 2010). Some records were prepared to portray an impression that certain non-performing loans granted in 2007 had been only recently granted in 2009. Furthermore, of the N26.78 billion worth of insider credits, N20 billion was non-performing. The bank's management deliberately repackaged some nonperforming credit in order to mislead the regulatory authorities. This amounted to a continual rendition of false returns.

Akingbola was indicted for conspiracy to grant unsecured credit facilities, conspiracy to manipulate share prices, reckless consideration of credit facilities without adequate security, and failure to present monthly statements of accounts to the CBN (EFCC News, 13 August 2010). In addition, seven non-executive directors and members of the Board of Directors of Intercontinental Bank were also arraigned. They were accused of making sure that the balance sheet of the bank did not give true and fair view of the state of affairs of the bank with regards to non-performing credit amounting to N87.6 billion (ThisDay, 1 September 2009). They all pleaded not guilty to the charges and were granted bail. In January 2012, Intercontinental Bank was sold to Access Bank by the CBN to get back the tax payers money used in saving it. Akingbola was cleared of all charges in April 2012.

Case 2 - Oceanic Bank

Oceanic Bank was a commercial and Investment bank in Nigeria. It was part of a family conglomerate business owned by the Ibru family. Cecilia Ibru became Oceanic Bank's Managing Director and Chief Executive Officer in 1997. She was the first female CEO to post over N1bn profit in a financial statement. In 2009, Cecilia Ibru was charged with financial crimes including money laundering and fraudulent conversion of depositors' funds for her own private gain. The CBN Governor alleged that the books of the financial institution that were examined by the central bank had huge non-performing loans. All the financial reports presented to the CBN and other regulatory agencies were falsified (Sunday Sun, 30 August 2009). Cecilia Ibru was indicted of using several companies to launder funds. She entered a plea bargain against the charges brought up by the Nigerian Economic and Financial Crimes Commission (EFCC).

Case 3 - Cadbury Nigeria

Cadbury Nigeria is a confectionary manufacturing corporation. Cadbury Nigeria was founded in 1965 as a subsidiary of Cadbury United Kingdom. Cadbury Nigeria's contribution is the second largest business (after South Africa) within the Group's operations in Africa, the Middle East and Turkey (AMET), and along with Ireland the fourth largest in Europe, the Middle East and Africa (EMEA) region. Early in 2006, Cadbury Schweppes Plc, the UK parent company made considerable effort to increase its shareholdings from $46 \%$ to $50 \%$. In the process of performing its due diligence of the Nigerian corporation, shocking overstatements were discovered in the books. 
In October 2006, the board of Cadbury Nigeria PLC declared to its stockholders and regulatory bodies of the discovery of overstatements in her accounts, which had spanned over a period of time (2003-2006). Price Water House Coopers (PWC), an independent audit firm was appointed to investigate these overstatements. The report submitted by PWC to the board of Cadbury PLC confirmed fraudulent accounting practices in the books of Cadbury Nigeria. Cadbury Nigeria stated that the overstatements were between 13billion and 15billion naira.

As a result of this scandal, Bunmi Oni, the CEO, and Ayo Akadiri, the Finance Director, were relieved from duty. Although the company did not accuse its sacked executive of personal gains, it did attribute the deliberate breaches in its accounting system and controls to efforts to achieve ambitious growth targets that were internally predetermined by its executives. As a result of the falsified accounts, Cadbury Schweppes Plc, the parent company had to make a provision of 15 million Pounds as impairment of the goodwill held in respect of Cadbury Nigeria (Solanke (2007)).

\section{The Governance Issues}

\section{Discussion}

\subsection{Directors' duty of care}

In Nigeria, the combined provisions of S. 282,331 to 334 of the Companies and Allied Matters Act, 2004, imposes on the board, the obligation of due care and skill in the preparation of their financial statements. The code of corporate practices (2003) states that the functions of the board include ensuring the integrity of financial controls and reports. The code specifies an overriding need to promote transparency in financial and non-financial reporting. It is the Board's duty to present a balanced, reasonable and transparent assessment of the Company's position. The prime responsibility for good internal controls lies with the Board. The directors are expected to report that the business is a going concern, with supporting assumptions or qualifications as necessary in compliance with the Companies and Allied Matters Act. It is evident that the board of directors of these organisations failed in their oversight function.

Intercontinental and Oceanic banks had been contravening BOFIA regulations on liquidity ratios and minimum capitals, these CEOs were giving out loans against little or worthless collateral. These CEOs granted loans to themselves; yet, the directors of the banks did nothing to stop it as most of them were either friends or family members of the CEOs chosen carefully as figureheads on the board. These banks issued no dividends or returns to shareholders while the CEOs and directors mismanaged the funds of the financial institutions.

The conflicts of interest of the directors of both banks are very evident. The directors' goal congruence was compromised as they had been granted loans from the banks.

They failed in their fiduciary obligation to raise the bar of enquiries. A director should know all that he possibly can about the business and financial operations of the corporation on whose board he serves. Cadbury Nigeria also shows a CEO with unfettered powers who with the finance director restated earnings for three years.

Cadbury had used stock buy backs, cost deferrals, trade loading and false suppliers' stock certificates to manipulate financial reports. Dividends were paid out on these reported false earnings, which raises the questions about the source of the funds used in paying the dividends. They borrowed money to pay dividends in line with the earnings restated increasing the leverage ratio of the organisation (Solanke 2007). The organisation using debt in paying its dividend should have raised concerns if it had an effective internal control system

The board of directors of Cadbury claimed ignorance; this is negligence on their part as the code of conduct states that these directors should be aware of the running of the corporation on which they sit on the board. The relevance of a board is an issue if the company's accounts can be overstated by 15billion and yet it found excuses for its negligence. According to the Code of governance post consolidation (2006) there should be a balance of power and authority so that no individual or coalition of individuals has unfettered powers of decision making. These bank CEOs were very domineering and had a stronghold on the board of directors. They were feared by the employees. $75 \%$ of the non-performing loans in Oceanic Bank were given to companies directly related to the CEO of the financial institution.

The approved limit for loans was N1 billion, but Cecilia Ibru of Oceanic Bank International unilaterally approved loans of N3 billion and above without recourse to the bank's Board. Akingbola granted loans to corporate customers who lacked audited financial statements and Memorandum and Articles of Association13. Furthermore, in many instances, the collateral values were less than the values of the credit granted (The News, 14 September 2009).

\subsection{Non- Executive Directors}

The independence of the non-executive directors in these corporations remains vague. Both the code of corporate governance (2003) and the code of practice post consolidation for banks (2006) emphasise the importance of the independence of non-executives directors. According to the code of corporate governance (2003) non-executive directors should ideally be independent and not be involved in business relationships with the company that could fetter or encumber their independent judgment. 
Investigations by the EFCC revealed that, despite the dwindling fortune of Intercontinental Bank, its board was approving a holiday allowance of $\$ 10,000$ each to non-executive directors, contrary to CBN's Code of Corporate Governance for banks in Nigeria which limits executive directors to sitting allowances (Thisday,1September 2009). In addition, seven non-executive directors in Intercontinental Bank granted various loans (without security) totalling over N36 billion to companies in which they were directors.

The independence of non-executive directors is an important part of the code of conduct for banks post consolidation as they are seen to protect the interests of shareholders. Non- executive directors expected to act on behalf of the shareholder's interests were enjoying bonus packages from the banks. The board of directors of the corporations failed in preventing the collapses because they were a party to the frauds and money laundering acts being perpetrated by the CEOs. The independence of non-executive directors in Oceanic bank was compromised. The bank had members of the Ibru family, the owners of the bank on the board as non-executive directors while a family member was also the CEO (Financial Statements 2009). Non-executive directors should bring independent judgement to bear on issues of performance, resources, including key appointments, and standards of conduct.

The lack of independence of some of the non-executive directors expected to protect the interests of the shareholders and a form of control on the board aided the control of the CEO on the board. Furthermore, the non-executive directors in Cadbury Nigeria did not have the financial backgrounds which could have aided their abilities in understanding the activities of the $\mathrm{CEO}$ and finance director. The number of non-executive directors should also exceed that of executive directors. These corporations failed in observing this law.

\subsection{Audit committee and External Auditors}

The audit committee was enacted by S. 359 of the CAMA. The audit committee should assist the board in fulfilling its oversight responsibilities. The audit committee is expected to review the financial reporting process, the system of internal control and management of financial risks, the audit process, and the Company's process for monitoring compliance with laws and regulations. The audit committee of Cadbury Nigeria did not follow up available leads which ought to put bring up enquiry in respect of the company's accounts.

They failed to examine the auditor's report and make proper recommendations. They neglected reviewing and making proper findings on management matters in conjunction with the external auditors and departmental responses. They also neglected managing financial risks and maintaining a viable system of internal control. The audit committee of Cadbury Nigeria failed to discharge their statutory responsibilities as specified under section 359(4) and (6) of the Companies and Allied Matters Act (CAMA).

Furthermore, according to the code of corporate governance the audit committee should not be under the influence of any dominant influence on the main board, neither should they get in the way and obstruct executive management. Akingbola the CEO was appointed as a member of the bank's audit committee which undermined the committee's independence, since one of its major responsibilities was to check the excesses of the Managing Director. The audit committees in both Intercontinental and Oceanic banks were under direct influence of the CEO of these corporations. This shows a contradiction of the law and a show of conflict of interests.

Given the magnitude of malfeasance uncovered by PWC, the independent auditors appointed for Cadbury Nigeria; it is impossible Akintola Williams Deloitte, the auditors of Cadbury Nigeria to have missed the restatement of earnings. How the auditors constructed audits to satisfy themselves that these banks were a going concern are open to conjecture.

PWC was the auditor of both Intercontinental and Oceanic Banks (Financial Statements 2007-2009). It failed to report the liquidity problems or the use of the expanded discounted window has a capital base. All these pointed out to corporations in trouble. However, PWC approved the financial reports of these organisations as true and fair which contradicts reports of independent inspectors appointed by the CBN.

There are long standing questions about auditors' provision of non-auditing services and the related impairment of auditor independence. PWC provided other financial services for these organisations apart from audit services. This is against the code of practice after consolidations requirements. PWC being a financial advisor suggests conflict of interests in the services provided by PWC.

\subsection{Internal Control and Risk management}

Internal control facilitates the effectiveness and efficiency of operations. It helps ensure the reliability of internal and external reporting and assists compliance with laws and regulations. Effective financial controls, including the maintenance of proper accounting records, are an important element of internal control. They help ensure that the company is not unnecessarily exposed to avoidable financial risks and that financial information used within the business and for publication is reliable. They also contribute to the safeguarding of assets; including the prevention and detection of fraud (Higgs report 2003). 
The internal controls of all the corporations were weak. Intercontinental bank was contravening the BOFIA, especially with respect to maintenance of minimum capital adequacy and liquidity ratios, treatment and use of commercial papers, and keeping of books of accounts which reflect a true and fair view of the financial position of the bank. The CBN governor emphasised, the bank had insufficient assets to cover its liabilities' (The News, 14 September 2009).

The banks failed to have the necessary capital base, had poor liquidity ratios; yet, these issues were not identified by the financial institutions internal auditors or analysts. The risks involved in dependency on the credit facilities of the EDW were not fully envisaged or ignored. It became a source of funds for these institutions instead of an emergency injection. Also, the internal auditors of these institutions made no objection to these, until these banks had accumulated more debt than they could manage.

The appointed auditors also discovered hidden non-performing loan facilities of N87.61 billion, contrary to s. 28(1) of the BOFIA 1991. Intercontinental and Oceanic bank had huge non-performing loans. Akingbola had granted loans to corporate customers who lacked collateral and others had collateral values less than the values of the credit granted. Cecilia Ibru approved loans of N3 billion above limit for loans which was N1 billion. These should have been detected by internal control systems of these organisations.

Akingbola used bogus institutions in siphoning money from the bank including Tropic Finance and Investments Ltd, an organisation run by his wife. An internal investigation of Intercontinental Bank, concluded on 21 December 2009, revealed that between 13 May and 30 June 2009 a total sum of N8.685 billion was converted and withdrawn from Intercontinental Bank and its subsidiaries for the benefit of Tropic Finance Ltd and other companies (EFCC News, 25 August 2010).

Cecilia Ibru used her companies; Cloudy Heights, Enifor, Prisky Gold, Bliss Bloss, Velvox and Circular Global to acquire over 1,509,983,560 billion shares in First Bank Nigeria, Union Bank of Nigeria and United Bank for Africa. Other acquisitions included 1,777,353,393 trillion shares in different Nigerian companies (The Sun, 9 October 2010). She also moved $£ 1.7$ billion to the United Kingdom in one transaction and the sum was subsequently transferred into other private foreign accounts. There were also approximately 57 properties fraudulently purchased in Lagos, Abuja and Port Harcourt Nigeria (oghajeflor 2010). All these acquisitions went unnoticed; this shows a lack of an internal control system in these corporations and a complete disregard for shareholder wealth. .

\subsection{Regulatory failures}

According to the CBN guidelines on expanded windows operations, the EDW was not allowed to be given to institutions with low liquidity ratios or poor capital bases. They were not allowed to be given out to organisations for a period more than 180 days and a specified cash reserve was expected of the financial institutions. These financial institutions did not meet these standards. Yet they were given this credit facility by the officials of the central bank of Nigeria.

The central bank expected to enforce these regulations failed in its duties. These banks continually made use of the EDW which is not the intent of the fund. They also did not meet the requirement for this facility which should have shown they were in trouble.

The SEC and CAC which are the monitoring agencies did not raise any objection to this practice which was very common amongst commercial banks in Nigeria. Furthermore, the SEC took several months in exercising its duty by conducting an investigation in Cadbury Nigeria. It is important to note the worn-off investor confidence, which SEC is expected to guide against. This easily undermines the markets in a transitional economy like Nigeria. The SEC should have moved instantly to examine Cadbury Nigeria once the scandal broke out, in order to emphasise and enforce the regulatory interest content of the scandal.

The Council of the Nigeria Stock Exchange barred Oni and Akadiri from Cadbury Nigeria and from running any publicly quoted company in Nigeria for life. This shows a conflict in roles played by the regulatory bodies as that was a role expected to be exercised the Nigerian SEC.

\section{Conclusion, Recommendation and Limitation}

In Nigeria, considerable emphasis is placed on the importance of financial success often with less regard being paid to the importance of using ethically acceptable means for achieving such success in the corporate world (Otusanya 2010). The literature reviewed emphasised the problems in the political system in Nigeria and how it encourages corruption in the financial sector. The corporate collapses in Nigeria are viewed as a result of the Nigerian socio-political and economic context. The Nigerian system is burdened with endemic corruption, lawlessness, nepotism and many other ills which mean employees may also be prone to corruption

In a country like Nigeria, where the endemic corruption has been emphasised a system of corporate governance that ensure accountability should be used. The UK combined code's (which is a major influence in the formation of the Nigerian codes) 'comply and explain' nature allows companies to explain reasons for noncompliance. This allows a level of freedom in its enforcement and makes its adoption easier. However, the US 
rules based code outlines the procedure for compliance which must be followed and has sanctions attached to it non-compliance. This seems more suitable for a country like Nigeria. Outlining rules and attaching sanctions ensures the liability of erring directors and ensures accountability.

A fair treatment of shareholders and their ability to have their voice heard is one of the major issues at the core of best corporate governance practice. Thompson D. (2012) argues that history has shown that increased regulation can never cover all possible forms of corporate abuse. However, Aguilera and Cuervo Cazurra (2004) suggested that there are at least two possible ways of achieving this aim of corporate accountability: one is for a country to reinvent its legal systems and the other is for a country to introduce new corporate governance practices into existing corporate governance systems. The Nigerian legal system as seen in this study has failed in enforcing the laid down laws. The need to reinvent the legal system in Nigeria cannot be overemphasised. Furthermore, qualified individuals should be recruited into the agencies established to enforce corporate accountability in Nigeria. Each agency should also have outlined responsibilities to allow easy enforcement of laws.

Furthermore, the question arises as to how probable it is that it was only CEOs of evaluated corporations that knew of the malfeasances. What about the first line officers, whose duty it was to generate the reports and accounts? What about the managers who oversee these line officers and would ideally have to interface with CEOs at the executive management level? What kind of organisational structure was in place in these corporations that allowed these CEOs to mindlessly, as reported, affect the financial health of the companies?

Otusanya (2010) suggested that if a few rotten apples can spoil the barrel, we have to look at the barrel not just the apples. The literature reviewed discussed lack of education and poverty as reasons preventing employees from blowing the whistle on their employers. However, in a country in Nigeria where the accumulation of wealth is very important, the organisational culture of amassing wealth plays a role in corporate scandals.

Okpara (2003) argued that companies develop their own methods that guide employees' thoughts and actions. That culture is a web of attitudes and practices that tend to replicate and perpetuate itself beyond the tenure of any individual manager. That culture may instil respect for the law or breed contempt and malfeasance. In a nation like Nigeria where corruption is embedded in corporate practices it may be argued that changing this culture may be a start in ensuring corporate accountability.

\section{References}

[1] Adekoya A, Corporate Governance Reforms in Nigeria: Challenges and suggested Solutions, Journal of Business Systems, Governance and Ethics. 6 (1) 2011, pp (38 -46)[1]

[2] World Bank (2007) Stolen Asset Recovery (StAR) Initiative: Challenges, Opportunities and Action Plan, World Bank, Washington DC.[1]

[3] World Bank, (1997) Helping Countries Combat Corruption: The Role of World Bank, available on-line at:http://www1.worldbank.org/publicsector/anticorruption/coruption/corrptn.pdf (accessed 31 April 2012).[1]

[4] Mellahi, The Dynamics of Boards of Directors in Failing Organisations, Long Range Planning (2005) 38 pp (261-279) [1]

[5] John O. Okpara, Corporate governance in a developing economy: barriers, issues, and implications for firms, Corporate Governance. 11 (2) 2011, pp (184 - 199)[1]

[6] Kariyawasam S. (2011) "Corporate Collapses -To What Extent does Failure to follow Corporate Governance Contribute". \{Online\} available at: http://www.apbsrilanka.org/general/03 articals/articals 23 ann.html accessed on 17 $7^{\text {th }}$ of April 2012.[1]

[7] Amaeshi, K \&. Amao, O, Galvanising Shareholder Activism: A Prerequisite for Effective Corporate Governance and Accountability in Nigeria', Journal of Business Ethics, 82 (1), 2008, pp. 119-130. [2]

[8] Otusanya J.O., Lauwo S., Adeyeye G.B, A Critical Examination of the Multinational Companies' Anti-Corruption Policy in Nigeria, Accountancy Business and the Public Interest. 2012 pp (1-49) [2]

[9] Oyejide and Soyebo

$$
\text { http://www.nigerianlawguru.com/articles/company\%20law/CORPORATE\%20GOVERNANCE\%20IN\%20NIGERIA.pdf }
$$

\{accessed on 14th Sept 2012\}[2]

[10] Emmanuel A., Chizu N, Corporate governance and responsibility in Nigeria, International Journal of Disclosure and Governance 8(3) $2011 \mathrm{pp}(252-271)$.[2]

[11] Adeyemi S. B., Fagbemi T.O, The perception of ethics in auditing profession in Nigeria, Journal of Accounting and Taxation Vol. 5(7), Nov 2011, pp. (146-157) [3]

[12] Company and Allied Matters Act (1991) \{online $\}$ available at: http://www.nigerialaw.org/CompaniesAndAlliedMattersAct.htm \{accessed on 1st of June 2012\} [3]

[13] Saunders, M., Lewis, P., \& Thornhill, A., "Research Methods for Business Students" (. Harlow: Financial Times Prentice Hall 2009). [3]

[14] Ugoji E.I and Isele G, Stress management and Corporate Governance in Nigerian Organisation, European Journal of Scientific Research (27) 32009 pp (472-478)[3]

[15] Bryman, A. and Bell, E. "Business research methods" (New York: Oxford University Press 2007)[4]

[16] EFCC News (2010) \{online\} available at: http://panafricannews.blogspot.co.uk/2009/08/nigeria-news-update-efcc-delcares.html \{accessed on 10th August 2012\}[4]

[17] EFCC News (2010) \{online\} available at: http://panafricannews.blogspot.co.uk/2009/08/nigeria-news-update-efcc-questions.html \{accessed on 10th August 2012\}[4]

[18] Solanke O.O., (2007) Corporate Governance Issues in Financial Reporting - The Cadbury Challenge. \{online $\}$ available at : http://www.nigeriavillagesquare.com/articles/oladele-o-solanke/corporate-governance-issues-in-financial-reporting-the-cadburychallenge.html accessed on $24^{\text {th }}$ of March 2012. [4] 
[19] The Guardian (2009) \{online\} available at: http://www.voiceofnigeria.org/Nigeria/11-Nigerian-banks-make-top-50-Africanbanks.html $\left\{\right.$ accessed $19^{\text {th }}$ July 2012$\}[4]$

[20] The Guardian newspaper (2009) \{online\} available at:http://panafricannews.blogspot.co.uk/2009/08/nigeria-news-update-cbn-andbubble-in.html $\left\{\right.$ accessed on $30^{\text {th }}$ July $\}$ [4]

[21] The News newspaper (2009) \{online\} available at: http://ngex.com/news/public/newsinfo.php?nid=9044 $\left\{\right.$ accessed on $30^{\text {th }}$ July 2012)[4]

[22] The Punch newspaper (2009) 'Nigeria's comatose capital market: Papering over the cracks (2)' \{online\} available at: http://www.punchng.com/opinion/nigerias-comatose-capital-market-papering-over-the-cracks/ $\left\{\right.$ accessed on 14 ${ }^{\text {th }}$ Sept 2012\}[4]

[23] The Sun newspaper (2009) \{Online\} available at: http://panafricannews.blogspot.co.uk/2009/08/nigeria-news-bulletin-centralbank.html \{accessed on 20th August 2012\} [4]

[24] The Sun Newspaper (2010)\{online\} available at: http://pmnewsnigeria.com/2012/09/12/akingbola-denies-n47-1b-efcc-fraudcharges/ $\left\{\right.$ accessed on $20^{\text {th }}$ August 2012\}[4]

[25] The Tribune Newspaper (2009) \{online\} available at: http://panafricannews.blogspot.co.uk/2009/08/nigeria-news-update-efccquestions.html \{accessed on 10th August 2012\}[4]

[26] Thisday Newspaper (2009) \{online\} available at: http://groups.yahoo.com/group/Naija-news/message/6097 $\left\{\right.$ accessed on $14^{\text {th }}$ September 2012)[4]

[27] Central Bank of Nigeria's Code of Corporate Governance for Banks in Nigeria Post Consolidation (2006) \{Online\} available at: http://www.cenbank.org/OUT/PUBLICATIONS/BSD/2006/CORPGOV-POSTCONSO.PDF \{accessed on 30th April 2012\}[7]

[28] Code of Corporate Governance in Nigeria (2003) \{online\} available http://www.ecgi.org/codes/documents/cg_code_nigeria_oct2003_en.pdf\{accessed on April 30th 2012\}[7]

[29] Higgs Report (2003) \{online\} available at: http://www.ecgi.org/codes/documents/combined_code_final.pdf \{accessed on 14th June $2012\}[8]$

[30] Oghojafor, B.E. A., Olayemi, O. O., Okonji, P. S. and Okolie, J. U, Poor Corporate Governance and its Consequence on the Nigerian Banking Sector, Serbian Journal of Management, 5 (2), 2010 243.350.[8]

[31] John O. Okpara, Perspectives on Corporate Governance Challenges in a Sub-Saharan African Economy, Journal of Business \& Policy Research. 5 ( 1). July 2011 Pp (110 - 122) [9]

[32] Thompson L. D. (2012) The Corporate Scandals, Why They Happened And Why They May Not Happen Again. Chautauqua Institution Lecture Brookings Accessed \{ march 16 2012\}\{9]

[33] Cuervo-Cazurra (2004) \{online $\quad$ available at:http://onlinelibrary.wiley.com/doi/10.1111/j.14678683.2009.00737.x/abstract?deniedAccessCustomisedMessage $=\& u$ serIsAuthenticated=false $\{$ accessed on 26th August 2012 $\}$ [9] 